The Student Guide to

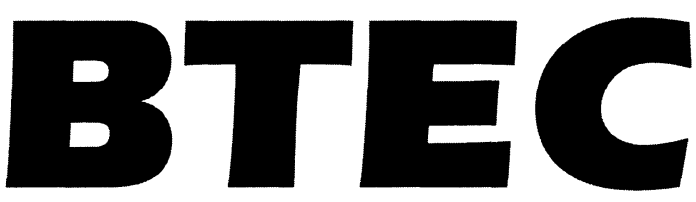

\title{
Business and Finance
}

Reg Chapman

Oldham College

Alistair Norman

Burnley College

Marie Norman

Bolton Institute

Series Editor: Alan Kitson

Bolton Institute 
(C) Reg Chapman, Alistair Norman and Marie Norman 1991, 1993

All rights reserved. No reproduction, copy or transmission of this publication may be made without written permission.

No paragraph of this publication may be reproduced, copied or transmitted save with written permission or in accordance with the provisions of the Copyright, Designs and Patents Act 1988, or under the terms of any licence permitting limited copying issued by the Copyright Licensing Agency, 90 Tottenham Court Road, London W1P 9HE.

Any person who does any unauthorised act in relation to this publication may be liable to criminal prosecution and civil claims for damages.

First edition 1991

Reprinted once

Second edition 1993

Published by

THE MACMILLAN PRESS LTD

Houndmills, Basingstoke, Hampshire RG21 2XS

and London

Companies and representatives

throughout the world

ISBN 978-0-333-58687-7

ISBN 978-1-349-13118-1 (eBook)

DOI 10.1007/978-1-349-13118-1

A catalogue record for this book is available

from the British Library

$\begin{array}{llllllll}10 & 9 & 8 & 7 & 6 & 5 & 4 & 3\end{array}$

0099989796959493 


\section{Contents}

Unit 1 Introduction

A job with prospects

Organisation of the book

Unit sequence

Unit layout

Activities

Unit 2 Learning with BTEC 8

What is BTEC? $\quad 8$

BTEC qualifications $\quad 8$

Why choose a BTEC National Business and Finance programme? $\quad 10$

What can you do after your BTEC programme? 16

Unit 3 Learning business and finance with BTEC 19

BTEC modules - built around business $\quad 19$

How do you learn on the National?

Reviewing what you have done $\quad 36$

Ways you learn 38

Who can help you to learn? $\quad 43$

Unit 4 Tackling assignments $\quad 48$

And your next assignment will be '...' 48

What types of assignment are there? $\quad 49$

Standard layout of assignments $\quad 50$

Tackling different types of assignment activities $\quad 51$

Work-based assignments $\quad 58$

Presenting your answers to assignments $\quad 61$

$\begin{array}{ll}\text { Handing the assignment in } & 70\end{array}$

Unit 5 Assessment $\quad 72$

What do you know already? $\quad 73$

What is assessed? $\quad 73$

How are you assessed? $\quad 76$

Are there any exams? $\quad 83$

Who assesses you? $\quad 84$ 
How are your grades recorded?

$\begin{array}{ll}\text { How are your final grades decided? } & 88\end{array}$

Problems - not meeting the standards $\quad 91$

$\begin{array}{ll}\text { Checklist of questions on assessment } & 94\end{array}$

Unit 6 Core assignments to practise on 95

Working with your tutor $\quad 95$

Assignment layout $\quad 96$

Sample assignments $\quad 96$

Unit 7 Assignment programmes 107

What is an assignment programme? 107

How many assignments are there in an assignment programme? 107

$\begin{array}{ll}\text { Managing self - your learning and studying skills } & 108\end{array}$

$\begin{array}{ll}\text { Sample assignment programmes } & 109\end{array}$

Unit 8 Sources of help and information 117

$\begin{array}{ll}\text { Help in your centre } & 117\end{array}$

Self-help $\quad 124$

Help locally $\quad 125$

Contacting people for help 126

Help further afield 128 